\title{
PUBLIC HEALTH NETWORK REPORT: TUBERCULOSIS
}

\section{PUBLICATIONS AND REPORTS}

Title: The prevalence of tuberculosis infection in New South Wales police recruits 1987-1990

Authors: Coolahan L, Levy M

Publication: Med J Aust 1993; 159;369-372

Contact: SE PHU

Title: Control and elimination of tuberculosis in Australia

Authors: Stewart G, Smith M

Publication: Med J Aust 1995; 163:50 (Letter)

Contact: SWS PHU

Title: The prevalence of tuberculosis infection in New South Wales police recruits, 1987-1990

Author: Stewart GS

Publication: Med J Aust 1993; 159:840 (Letter)

Contact: SWS PHU

Title: Tuberculosis screening in inmates and staff of a NSW jail

Authors: Sladden T, O'Donnell J, Levy M

Publication: NSW Public Health Bulletin 1995; 6:19-20

Contact: NC PHU

Title: The prevalence of tuberculosis infection among Year 8 school children in inner Sydney in 1992

Authors: Alperstein G, Fett MJ, Reznik R, Thomas M, Senthil M

Publication: Med J Aust 1994; 160:197-201

Contact: Central Sydney AHS

Title: Surveillance for tuberculosis among residents of hostels for homeless men

Authors: Lau E, Ferson MJ

Publication: Aust NZ J Public Health 1997 (in press)

Contact: SES PHU
PUBLIC HEALTH PROGRAMS AND RESEARCH

Title: Prevalence of tuberculosis infection among Year 8 children in Central and Southern Sydney (completed)

Contact: Central Sydney AHS

Title: Prevalence of tuberculosis infection in Year 1 children in Central, Southern and South-western Sydney (completed)

Contact: Central Sydney AHS

Title: Epidemiology of tuberculosis in NSW (completed)

Contact: SWS PHU

Title: Evaluation of tuberculosis program outcome indicators in South Western Sydney. Evaluation of targeted intervention to minimise the delay in diagnosis of tuberculosis (completed)

Contact: SWS PHU

Title: Contact tracing - how effective is it? (completed)

Contact: SES PHU and Respiratory Medicine, Prince of Wales Hospital

Title: Strategic plan for tuberculosis in the NSAHS (in progress)

Contact: NS PHU

Title: Tuberculosis screening in a juvenile detention centre on the Central Coast (in progress)

Contact: CC PHU and Gosford Chest Clinic

(Compiled by the South West Centre for Public Health on behalf of the Public Health Network) 
NSW PUBLIC HEALTH UNITS

\begin{tabular}{|c|c|c|c|c|}
\hline Code & Unit & Address & Phone & Facsimile \\
\hline $\mathrm{CCPHU}$ & Central Coast Public Health Unit & PO Box 361, GOSFORD NSW 2250 & 043204545 & 043204550 \\
\hline CS PHU & Central Sydney Public Health Unit & PO Box 374, CAMPERDOWN NSW 2050 & 0295153180 & 0295153182 \\
\hline MW PHU & Mid-Western Public Health Unit & PO Box 143, BATHURST NSW 2795 & 063328505 & 063328555 \\
\hline SES PHU & South Eastern Sydney Public Health Unit & Locked Bag 88, RANDWICK NSW 2031 & 0293138322 & 0293136291 \\
\hline HUN PHU & Hunter Public Health Unit & PO Box 466, WALLSEND NSW 2287 & 049246477 & 049246490 \\
\hline ILL PHU & Illawarra Public Health Unit & PO Box 66, KEIRAVILLE NSW 2500 & 042264677 & 042264917 \\
\hline NRPHU & Northern Rivers Public Health Unit & PO Box 498, LISMORE NSW 2480 & 066217231 & 066222151 \\
\hline NE PHU & New England Public Health Unit & PO Box 597, TAMWORTH NSW 2340 & 067662288 & 067663003 \\
\hline \multirow[t]{2}{*}{ NS PHU } & Northern Sydney Public Health Unit & Hornsby Ku-ring-gai Hospital, & & \\
\hline & & Palmerston Road, HORNSBY NSW 2077 & 0294779400 & 0294821650 \\
\hline S PHU & Southern Public Health Unit & Locked Mail Bag 11, GOULBURN NSW 2580 & 048273428 & 048273438 \\
\hline SW CPH & South West Centre for Public Health & PO Box 503, ALBURY NSW 2640 & 060581700 & 060581701 \\
\hline SWS PHU & South Western Sydney Public Health Unit & Locked Bag 17, LIVERPOOL NSW 2170 & 0298285944 & 0298285955 \\
\hline M PHU & Macquarie Public Health Unit & PO Box M61, EAST DUBBO NSW 2830 & 068812235 & 068847223 \\
\hline WS PHU & Western Sector Public Health Unit & 13 New Street, NTH PARRAMATTA NSW 2151 & 0298403603 & 0298403608 \\
\hline
\end{tabular}

\section{PUBLIC HEALTH EDITORIAL STAFF}

The editor of the NSW Public Health Bulletin is Dr Michael Frommer, Director, Centre for Research and Development, NSW Health Department. Dr Lynne Madden is production manager.

The Bulletin aims to provide its readers with population health data and information to motivate effective public health action. Articles, news and comments should be 1,000 words or less in length and include a summary of the key points to be made in the first paragraph. References should be set out using the Vancouver style, the full text of which can be found in British Medical Journal 1988; 296:401-5.

Please submit items in hard copy and on diskette, preferably using WordPerfect, to the editor, NSW Public Health Bulletin, Locked Mail Bag 961, North Sydney 2059. Facsimile (02) 93919029.

Please contact your local Public Health Unit to obtain copies of the NSW Public Health Bulletin.

The Bulletin can be accessed via the Internet from the NSW Health Department's World Wide Website, at

http:/www.health.nsw.gov.au/public-health/phb/phb.html

Back issues can be obtained from the Better Health Centre, Locked Mail Bag 961, North Sydney 2059.

Telephone: (02) 9954 1193, Facsimile (02) 99555196. 